\title{
Chapter 8 \\ Why Should We Preserve Fishless \\ High Mountain Lakes?
}

\author{
Marc Ventura, Rocco Tiberti, Teresa Buchaca, Danilo Buñay, \\ Ibor Sabás and Alexandre Miró
}

\begin{abstract}
High mountain lakes are originally fishless, although many have had introductions of non-native fish species, predominantly trout, and recently also minnows introduced by fishermen that use them as live bait. The extent of these introductions is general and substantial often involving many lakes over mountain ranges. Predation on native fauna by introduced fish involves profound ecological changes since fish occupy a higher trophic level that was previously inexistent. Fish predation produces a drastic reduction or elimination of autochthonous animal groups, such as amphibians and large macroinvertebrates in the littoral, and crustaceans in the plankton. These strong effects raise concerns for the conservation of high mountain lakes. In terms of individual species, those adapted to live in larger lakes have suffered a higher decrease in the size of their metapopulation. This ecological problem is discussed from a European perspective providing examples from two study areas: the Pyrenees and the Western Italian Alps. Species-specific studies are urgently needed to evaluate the conservation status of the more impacted species, together with conservation measures at continental and regional scales, through regulation, and at local scale, through restoration actions, aimed to stop further invasive species expansions and to restore the present situation. At different high mountain areas of the world, there have been restoration projects aiming to return lakes to their native fish-free status. In these areas autochthonous species that disappeared with the introduction of fish are progressively recovering their initial distribution when nearby fish-free lakes and ponds are available.
\end{abstract}

\footnotetext{
M. Ventura $(\bowtie) \cdot$ T. Buchaca · D. Buñay · I. Sabás · A. Miró Integrative Freshwater Ecology Group, Center For Advanced Studies of Blanes (CEAB-CSIC), Accés a la Cala St. Francesc, 14, Blanes, Girona, Catalonia, Spain e-mail: ventura@ceab.csic.es

R. Tiberti

Dipartimento di Scienze della Terra e dell'Ambiente (DSTA), University of Pavia, Via Ferrata 9, 27100 Pavia, Italy

R. Tiberti

Alpine Wildlife Research Centre, Gran Paradiso National Park,

Degioz 11, 11010 Valsavarenche, Aosta, Italy

(C) The Author(s) 2017

J. Catalan et al. (eds.), High Mountain Conservation in a Changing World,

Advances in Global Change Research 62, DOI 10.1007/978-3-319-55982-7_8
} 
Keywords Global change - Introduced species • Trout • Minnows • Amphibians • Restoration - Conservation • High mountain lakes

\subsection{Introduced Species, a Global Threat to Freshwater Ecosystems}

Among the biomes of the planet, freshwaters have suffered the strongest decline in the number of vertebrate species during 1970-2010 (76\% in freshwaters compared to $39 \%$ in the other two biomes; McRae et al. 2014). This great decline is a result, on a global scale, of factors related to habitat destruction, pollution, water-level reductions and invasive species among others (Collen et al. 2014). Although these factors are affecting all species within the habitats, amphibians are amongst the most threatened freshwater groups (Collen et al. 2014).

In Europe, freshwater fish are one of the animal groups with a higher number of invasive species (Hulme et al. 2009). The introduction of freshwater fish is closely related to human activities (Gido et al. 2004; Marchetti et al. 2004) and especially to fishing in the case of salmonids (Cambray 2003; Cowx and Gerdeaux 2004; Granek et al. 2008). The circumstances and timing of recent arrival of some species have been documented worldwide (FAO 2003) and in some particularly well-studied lakes (Villwock 1994; Pringle 2005; Volta and Jepsen 2008). In other cases, it has been possible to describe the introductions that have suffered different lakes using historical reconstructions (Emery 1985; Garcia-Berthou and Moreno-Amich 2000; Brancelj et al. 2000; Buchaca et al. 2011). Previous studies show that the introduction of freshwater fish can often have significant negative ecological consequences (Vitule et al. 2009).

High mountain lakes are usually isolated from lower streams by physical barriers that have prevented natural colonisation of fish (Pechlaner 1984; Knapp et al. 2001a; Miró and Ventura 2013). In these ecosystems, the introduction of fish species is mainly related to recreational fishing and promoted by different administrations (Pister 2001; Schindler and Parker 2002). There is detailed information on the historical evidences of the spread of salmonids in some high mountain areas of the western United States (Christenson 1977; Bahls 1992; Knapp 1996; Wiley 2003) and the Canadian Rockies (Schindler 2000). In these areas, introductions are described chronologically from the end of nineteenth and beginning of twentieth centuries and they were initially made by individual fishermen, and a few decades later by the Governmental agencies (Christenson 1977; Schindler 2000). In contrast to these areas, the information about the stocking history in other mountain ranges is difficult to access. In particular the information from the high mountain ranges of Asia (Petr 1999) and South America (Vigliano and Alonso 2007; Martín-Torrijos et al. 2016) are insufficient, because of uncontrolled stocking (Vigliano and Alonso 2007; Ortega et al. 2007).

In contrast to the American continent, in European high mountain lakes the colonisation process has not been studied in detail (Gliwicz and Rowan 1984; 
Pechlaner 1984; Sostoa and Lobón-Cerviá 1989). The first introductions in the Alps were carried out at the end of the sixteenth century (Pechlaner 1984) and in the Tatra mountains at the end of the nineteenth century (Brancelj 2000; Gliwicz and Rowan 1984). In the Cantabric mountains (Iberian Peninsula) introductions also occurred at the end of the nineteenth century (Terrero 1951) and even more recently in the Sistema Central and Sistema Ibérico, also in the Iberian Peninsula (Martinez-Solano et al. 2003; Toro et al. 2006). In the Pyrenees, the first fish introductions took place at least during the middle ages, being the first written evidence of fish presence from the fourteenth century (Miró 2011).

In conclusion, we know that introduced fish are present in high-altitude aquatic habitats in many mountain ranges all around the world, but we are not aware of the exact spatial extent of their distribution (e.g. the percentage and features of stocked lakes at a regional scale). We also know that except a very few medieval and some pre-industrial introductions occurred in Europe, the majority of the introductions started during the nineteenth century and in particular in the second half of the twentieth. Indeed in the past decades, a critical acceleration of the invasion has been promoted by different governmental agencies, supporting the growing popularity of recreational angling (Pister 2001; Schindler and Parker 2002).

\subsection{The Process of Species Introductions in the Alps}

The first documented fish introductions in the Alps were carried out during the middle Age, at the end of the sixteenth century, probably during the reign of Kaiser Maximilian I (Pechlaner 1984). However, similarly to most mountain ranges across Europe, most of the fish introductions took place in the recent decades to support recreational angling. In Italy, the phenomenon became particularly evident from the 1960s onwards when, recreational angling became a popular activity (Cantonati et al. 2006). The presence of introduced species such as Salmo trutta L 1758 or species from across the Atlantic Ocean, such as Oncorhynchus mykiss (Walbaum 1792) and Salvelinus fontinalis (Mitchill 1814) is common all around the Alps. Moreover Salvelinus umbla (L 1758) have been introduced across the Italian Alps (Zerunian 2003). Restocking with $S$. umbla is considered a conservation measure in some Alpine regions, even if its status as an indigenous species in Italy has given rise to serious doubts (Pechlaner 1984; Machino 1999; Piccinini et al. 2004) and the fact that this species does not require ex situ conservation actions. Also the marble trout (Salmo marmoratus Cuvier, 1829), an alpine endemism, was sometimes introduced in alpine lakes, as well as Salvelinus namaycush (Walbaum 1792) from North America. Finally cyprinids, used as live baits by anglers, are accidentally or voluntary released in many high-altitude lakes, and minnows (Phoxinus sp.) are able to establish reproductive populations.

For the Alps, a detailed and coherent history of the fish introductions is not available: information is often insufficient and still scattered in many archives and grey literature. Also, the distribution of introduced fish has rarely been assessed 
over large regions. In a study conducted in the Eastern Alps, Jersabek et al. (2001) report that the $41 \%$ of the high-altitude lakes ( $>0.5$ ha, above $1300 \mathrm{~m}$ a.s.l.) present fish fauna; in Valle d'Aosta (Western Alps), where the first documented fish introductions date back to 1926 (Mammoliti Mochet 1995), an accurate catalogue of all the ponds and lakes (Frezet 2003) indicate that the $43 \%$ of the lakes $(>0.5$ ha, above $1000 \mathrm{~m}$ a.s.1.) present fish fauna and this percentage increase to the $50 \%$ excluding those lakes above $2900 \mathrm{~m}$ a.s.l., where fish survival is challenged by the extreme temperatures and glacial influence; in the Gran Paradiso National Park (Western Alps) $35 \%$ of all the lakes ( $>0.5 \mathrm{ha}$ ) is occupied by fish (RT personal observation). These percentages are similar to those observed in other mountain ranges (Miró and Ventura 2013; Bahls 1992).

\subsection{The Process of Species Introductions in the Pyrenees}

The different fish species described to be introduced in the Pyrenees include the salmonids $S$. trutta, O. mykiss and S. fontinalis, and the cyprinid Phoxinus sp. in the southern (Spanish) Pyrenees (Miró and Ventura 2013, 2015) and these species together with $S$. umbla and $S$. namaycush in the northern (French) Pyrenees (Delacoste et al. 1997). At a global scale, S. trutta and O. mykiss are considered among the 100 most invasive alien species in the world (Lowe et al. 2000). Within Europe, O. mykiss, S. fontinalis and S. namaycush have been introduced from North America, while $S$. trutta and $S$. umbla that are native European species have been widely introduced beyond their native range, mostly in high mountain areas. Therefore, they are all classified as European alien species (Hulme et al. 2009).

\subsubsection{Trout Introductions}

The oldest written documents describing fishing rights in high mountain lakes of the Pyrenees date back to the fourteenth and fifteenth centuries (Miró 2011). These initial introductions for traditional exploitation resulted in $26.5 \%$ of the lakes of the southern slope of the Pyrenees having introduced trout by 1900 (Fig. 8.1; Miró and Ventura 2013). Similarly, on the northern side of the Pyrenees, it has been described that ca. $25 \%$ of the lakes had fish before the onset of widespread introductions after 1936 (Delacoste et al. 1997), which might also be attributed to traditional fishing activities by local fishermen. Miró and Ventura (2013) findings suggest that human exploitation of some of these lakes might have originated further back in time, possibly back to prehistoric times, when primitive residents already used the high-altitude pastures (Miró 2011). However, written evidence suggests that the first major historical introductions occurred within the medieval warm period (1000-1300 AD) when the human population in the Pyrenees was highest (Miró 2011). 


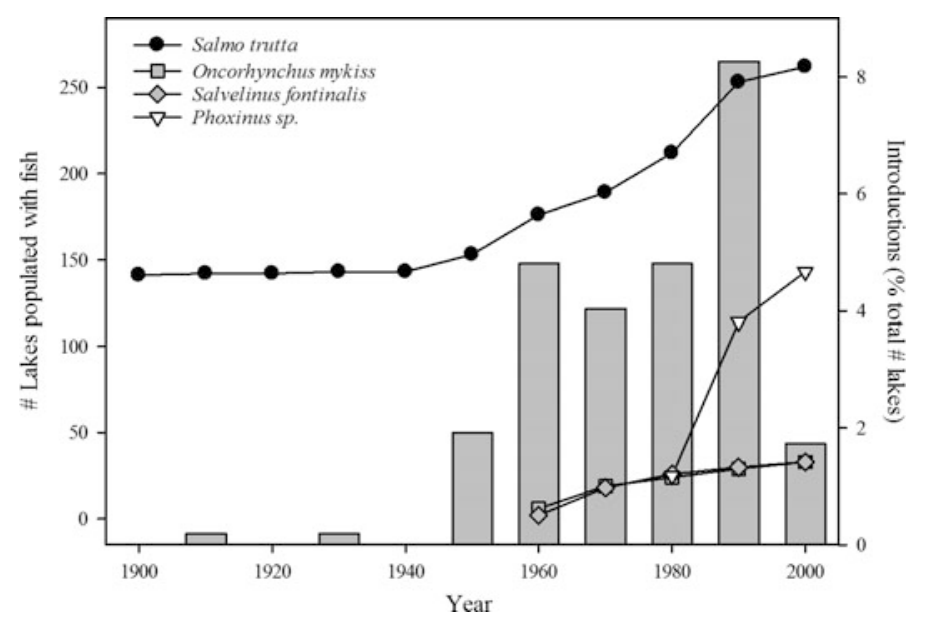

Fig. 8.1 Introduction process of non-native fish species in the southern Pyrenees during the twentieth century. Vertical grey bars are the decadal total number of lakes that have suffered fish introductions as a percentage of the total number of lakes $>0.5$ ha of the study area $(n=520)$. Data from Miró and Ventura $(2013,2015)$

With the onset of modern fish management that took place during the period 1960-2000, the most significant factors explaining trout distribution were related to management practices (Miró and Ventura 2013). However, different factors were important for the different species. For $S$. trutta, the probability of occurrence was highest in areas where fish were stocked by helicopter, and in fish-managed areas. The repeated use of helicopter stocking in recent decades has resulted in an extensive occurrence of trout in these areas and, as a result, in more than half of the lakes with fish. This result is similar to that found in other parts of the world where helicopters and aeroplanes have been used for stocking trout, such as several mountain areas of West USA, where trout is present in ca. 60\% of lakes (Bahls 1992).

In contrast to $S$. trutta, $S$. fontinalis was preferentially found in lakes with forestry road access, while $O$. mykiss was also found in lakes with road access but where active fish management has been carried out. These two last species are present in a much lower number of lakes, and also were introduced mainly between 1960 and 1980 (Fig. 8.1). Their presence is closely linked to the construction of the majority of hydroelectric power station infrastructure at high altitudes in the Pyrenees (Catalan et al. 1997). Hydroelectric companies compensated local citizens by developing local fisheries that were used to introduce these two species to the lakes around the area, where hydroelectric power station infrastructure was constructed. The same hydroelectric infrastructure construction was responsible for the forestry roads that were, in turn, the main routes facilitating the introduction of these two species. Amongst the species, S. fontinalis was mainly introduced in lakes with vehicle access. In the 1980s, administrative changes shifted stocking responsibilities to local fishermen's societies together with governmental agencies. This fact favoured the closure of $S$. fontinalis and $O$. mykiss hatcheries and the introduction of 
the north and central European lineages of $S$. trutta in official fish hatcheries. As a result, there has been a shift to using lineages from different parts of central and northern Europe (Araguas et al. 2009). Modern management practices have therefore resulted in increased fish introductions during the past few decades with a maximum during the 1990s (Fig. 8.1). As a result, trout have been introduced in most lakes with higher fishing interest (e.g. lower altitude or bigger surface area). The low number of lakes remaining without fish after the 1990s is likely the reason why fish introductions dropped considerably during 2000.

\subsubsection{Collateral Introductions}

The salmonid introductions described above have resulted in collateral introductions of other fish species mainly used as live bait (Miró and Ventura 2015). This fact may eventually lead to stronger ecological consequences than the introduction of trout alone. In the Pyrenees, Miró and Ventura (2015) found that the introduction of minnows in high mountain lakes was mediated by a preceding invasive species and facilitated by human activity. They found that the introduction of the minnow is a more recent and faster process than that of salmonids (Fig. 8.1). Since 1970, when the first minnow introduction took place, it has now spread to $27 \%$ of the lakes of the southern Pyrenees with an introduction rate of 4.7 lakes per year, compared to those of trout, at 2.2 lakes per year for the period between 1940 and 2000 (Miró and Ventura 2015).

Differences in minnow life history characteristics compared to those of trout give them a higher acclimation success and therefore high invasive potential. The minnow, like other small widely distributed freshwater fish, displays a remarkable variability in its life history depending on the local temperature. For example, minnows have maximum age ranges between 3 and 13 years reaching maturity between 1-2 and 5-7 years in optimal and sub-optimal conditions respectively, and show significantly lower growth increments in cold summers (Mills 1988). This plasticity in their life history is what has allowed the species to easily acclimate to high mountain lakes, showing higher resistance to harsh conditions than trout. Miró and Ventura (2015) have not found any lake where minnows have disappeared once established. In contrast, in lakes with trout, between 10 and $44 \%$ of the trout populations have become extinct after 20-30 years due to a lack of favourable conditions (Knapp 2005; Armstrong and Knapp 2004; Miró and Ventura 2013). Moreover, in the Pyrenees, Miró and Ventura (2015) have found that in twenty lakes and ponds, pre-existing trout populations have disappeared after minnow introductions. Some of these lakes and ponds had brown trout introduced centuries ago while others were stocked recently.

Miró and Ventura (2015) also found that minnow presence was more likely in lakes with lower elevation, greater surface areas and higher temperatures. This distribution could be a result of the pattern of introductions (e.g. fishermen using live bait do not fish so often at the upper altitude lakes) or to fair habitat conditions 
for released minnows to become established. Taking into account the high plasticity of minnows, it seems more likely that their presence was a result of the pattern of introduction. As well as minnows, other species might be used as live bait, increasing the number of invasive species to lakes. This is the case for gudgeon (Gobio spp.), which is now found in some lakes of the northern slope of the Pyrenees (Miró 2011). This fish has similar size and flexible life history features to those of minnows (Tang et al. 2011). Thus, the ecological effects of fish introductions in high mountain lakes can result in stronger unpredicted consequences.

Live bait-related introductions of minnows have occurred in lower, boreal and arctic lakes where trout is present. The distribution of minnow expanded considerably throughout the twentieth century in the north European lakes of Scotland and Norway, especially in mountain areas, due mainly to the use of minnows as live bait for angling (Maitland and Campbell 1992; Museth et al. 2007). When minnow is introduced in lakes with autochthonous trout, it reduces recruitment and annual growth rates of trout, causing a decrease of the trout abundance by $35 \%$ on average; however, the effect on other native fauna takes place primarily in the shallow littoral areas (Museth et al. 2007).

Angling practices with live bait represents a worrying pathway for alien species introductions (Kerr et al. 2005; Webb 2007; DiStefano et al. 2009; Ward et al. 2012). The largest organisms used as live bait are several species of small fishes, but other animals such as amphibians, earthworms, crayfishes, grubs and insects are also used (Lindgren 2006; Keller and Lodge 2007). Improper disposal of live bait has been attributed as the source of introduction of at least 14 species of fishes in Ontario (Kerr et al. 2005). In the English Lake District, individuals of at least 12 native and non-native fish species have been brought to Windermere for the purpose of live baiting (Winfield et al. 2011). Live bait use was also responsible for the introduction of 47 known freshwater species in United States Mid-Atlantic slope drainage systems, among which are at least 5 non-native fishes, 4 non-native crayfishes and 9 non-native earthworm species (Kilian et al. 2012). Live baits may be released to the medium by accidental escape or, more often, by purpose at the end of the fishing trip (Winfield et al. 2011; Kilian et al. 2012). In some cases, it has been shown that bait-related introductions have resulted in established populations of invasive species (e.g. Callaham et al. 2006; Migge-Kleian et al. 2006).

In high mountain lakes, trout are the only species group authorised for introduction by governmental agencies worldwide (e.g. Sostoa and Lobón-Cerviá 1989; Wiley 2003), mainly associated with recreational fishing (Cambray 2003). Unlike trout, minnow introductions are in general not authorised by governmental authorities, and their introduction is often an illegal angling practice. As mentioned, the final result in many cases is that fish unused as live bait are released at the end of the fishing expedition (Maitland and Campbell 1992; Kerr et al. 2005; Winfield et al. 2011; Kilian et al. 2012). This practice has been quantified to be done by $36 \%$ of the fishermen in Michigan and Wisconsin, $41 \%$ in Ontario and 65\% in Maryland (Litvak and Mandrak 1993; Kerr et al. 2005; Kilian et al. 2012). To prevent the widespread release of non-native species used as live bait, many US states and Canadian territories have restricted the use, sale or transport of bait (Kerr et al. 
2005; Peters and Lodge 2009). A similar situation exists on the southern slope of the Pyrenees, where the release of any organism to the environment without government authorization is also strictly prohibited (Miró 2011). Nevertheless, similar to the findings from the southern valleys of the Pyrenees, in some regions of North America a large proportion of anglers appear to be unaware of, or choose to ignore, the current regulation forbidding the release of live organisms because they believe their actions are compassionate and that the released unused bait is a suitable food for angling fishes (Kerr et al. 2005; Kilian et al. 2012). The results described above strongly suggest the need to intensify preventive actions by giving accurate information of the potentially adverse effects on the local environment of the release of non-native organisms to fisheries boards and local communities. These actions are one of the best guiding principles to prevent the spread of invasive species together with regulation and legislation (Simberloff et al. 2013).

\subsection{Ecological Consequences}

The implications of stocking into high mountain lakes derive primarily from the fact that fish occupy a higher trophic level that was previously inexistent leading to profound ecological changes. Their introduction in fishless lakes is commonly associated with extirpation or reduction of native aquatic species (e.g. invertebrates and amphibians) and can have indirect effects on the whole ecosystem, and on its linkage with the surrounding terrestrial habitats (Eby et al. 2006). From high altitude lakes, fish can colonise otherwise inaccessible downstream aquatic habitats often propagating the ecological impact at a whole basin scale (Adams et al. 2001).

The studies concerning the ecological impact of introduced fish in high-altitude lakes are strongly biased towards the impact of salmonids, even if minnows and other small species are likely to become - or already are - a serious conservation problem in the near future. Since trout are visual predators, most of the direct impacts are attributable to their size selective predation strategy, affecting only larger non-fossorial taxa (Knapp et al. 2001b; Tiberti et al. 2014a, b). Published studies from different mountain regions of the world have focused mainly on the effects of trout introductions that produce a drastic reduction or elimination of those autochthonous animal groups of bigger size. Threatened groups live mostly in the littoral and benthic zones and include amphibians (Knapp 2005; Orizaola and Braa 2006; Pope 2008; Pope et al. 2008; Pilliod et al. 2010; Tiberti and von Hardenberg 2012; Bosch et al. 2006; in particular those with aquatic larval stages; Bradford et al. 1993; Martinez-Solano et al. 2003; Tiberti et al. 2014b) and conspicuous macroinvertebrates (Knapp et al. 2001b; Pope et al. 2009; de Mendoza et al. 2012; Pope and Hannelly 2013; Tiberti et al. 2014b; Fig. 8.2). The effects on amphibians are of special concern, since they are one of the most threatened animal groups worldwide (Beebee and Griffiths 2005).

The effects of trout on the plankton are less predictable, basically due to the smaller size of the planktonic animals, and the biology of the introduced 

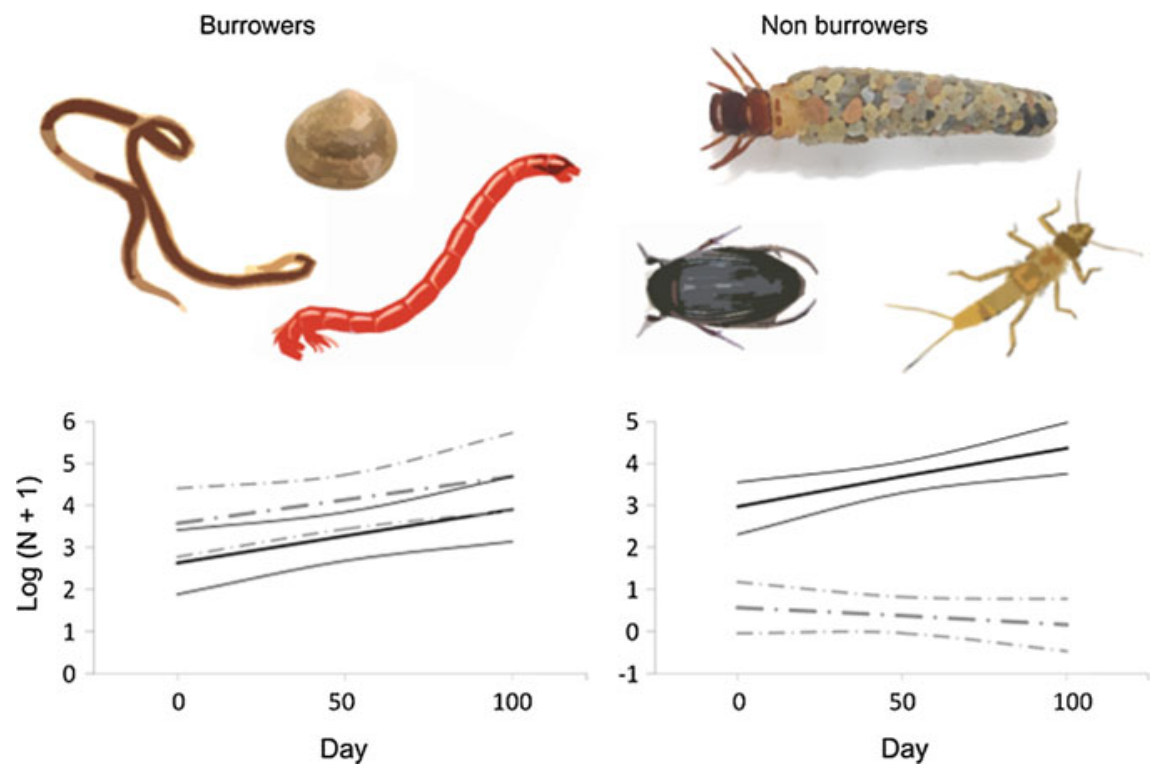

Fig. 8.2 Seasonal trend of abundance from day 0 (15 June) to day 100 (23 September) of littoral macroinvertebrates in naturally fishless (solid line) and stocked (dashed lines) lakes. While borrowing taxa are unaffected or even indirectly favoured by fish presence, nectonic and benthonic taxa (non-borrowers) are very sensitive to fish predation. Modified from Tiberti et al. (2014b)

species/populations, which can be more or less planktivorous. However, larger crustaceans have also decreased their abundance and body size, or disappeared from some high mountain lakes with stocked fish (Fig. 8.3; Brancelj 2000; Knapp et al. 2001b; Tiberti et al. 2014b). Among salmonids, this impact has been described in particular for S. fontinalis, which is a generalist predator and which can rely on large zooplankton species as a temporary or seasonal resource, especially during the winter (Knapp et al. 2001b; Schabetsberger et al. 2009; Tiberti et al. 2014b; Dawidowicz and Gliwicz 1983).

Direct predation of more visible taxa can produce a series of indirect ecological effects (top-down and cascading effects) which affect the entire ecosystem (Hall et al. 1976; Schindler et al. 2001; Sarnelle and Knapp 2005; Eby et al. 2006). The decrease of large zooplankton species can produce a competitive release of small zooplankton species (e.g. rotifers), which are less efficient grazers (Brooks and Dodson 1965). Therefore, a decrease in crustaceans together with enhanced nutrient cycling have led to changes in primary producers (Sarnelle and Knapp 2005; Magnea et al. 2013).

The effect on benthic macroinvertebrates is also important during their emergency phase, when passing through the water column, which results in a substantial reduction or alteration of their emergency rates (Pope et al. 2009; Epanchin et al. 2010; Tiberti et al. 2016b). This is also linked with indirect effects on surrounding habitats through resource depletion for terrestrial insectivores (Epanchin et al. 2010; 


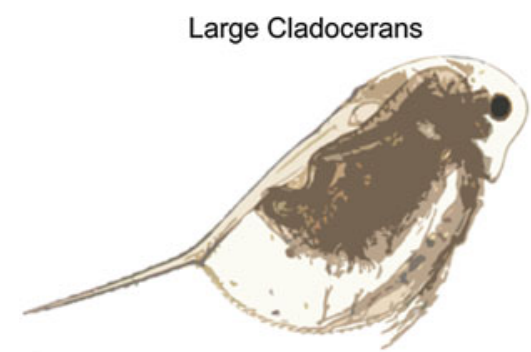

Large Copepods
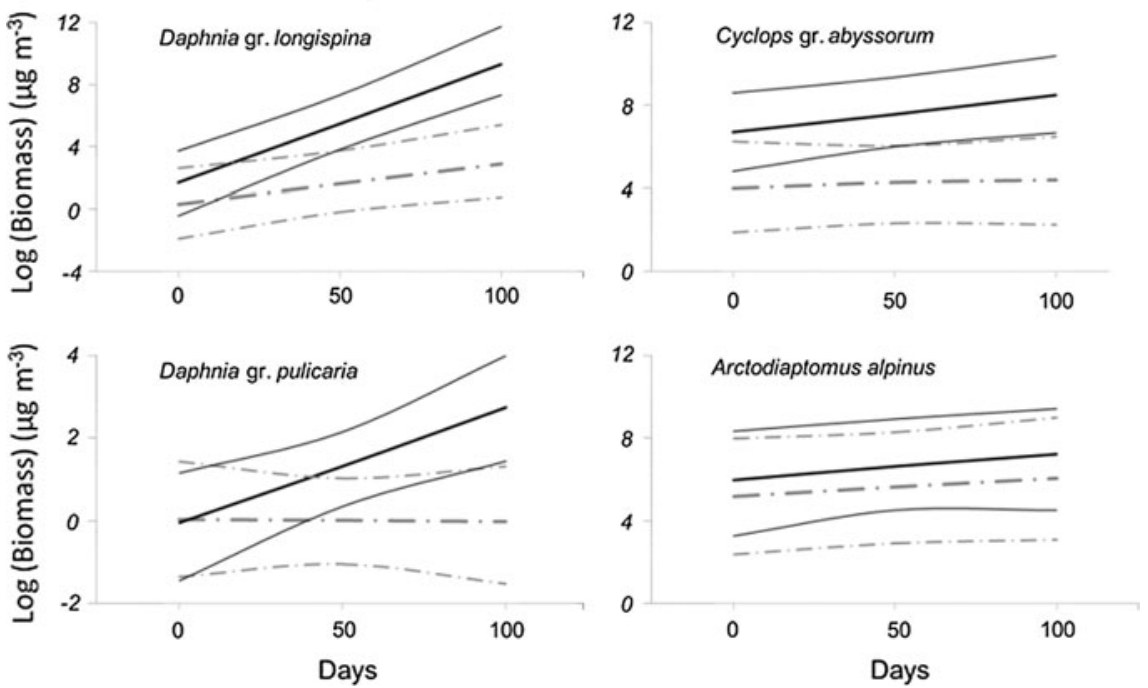

Fig. 8.3 Seasonal biomass trends from day 0 (15 June) to day 100 (23 September) of the large $(>1 \mathrm{~mm})$ zooplankton species in fishless (solid line) and stocked (dashed lines) lakes. With the exception of Arctodiaptomus alpinus, the biomass of large zooplankton species is significantly larger and its increment is significantly faster in fishless lakes. Modified from Tiberti et al. (2014b)

Eby et al. 2006; Finlay and Vredenburg 2007). Similarly, a reduction of the amphibians' emergence can affect terrestrial habitats and predators (Matthews et al. 2002). In the complex, aquatic subsidies depletion by introduced fish can have deep and detectable, indirect cascading effects in terrestrial habitats (Knight et al. 2005; Gratton et al. 2008).

On the other hand, the effects of minnow introductions on high mountain lakes have scarcely been studied in comparison with those of trout. Regardless of their smaller size, minnows are also occupying the top of the food chain (Hesthagen et al. 1992; Borgstrom et al. 1985; Museth et al. 2010), and when co-occurring with salmonids remain mainly in the littoral to escape trout predation (Museth et al. 2003). However, minnows are also the main cause for a reduction in trout reproduction (Borgstrøm et al. 1996) that leads to trout disappearances in some high mountain lakes (Miró and Ventura 2015). In this case, minnow seem to have a strong impact on amphibians and macroinvertebrates, but also on crustacean 
biomass (Schabetsberger et al. 1995), that might result in a strong trophic cascade, as has been described for other lakes such as those from the north-temperate area (Carpenter et al. 2011).

Even if the effects listed above (see Fig. 8.4 for a schematic summary) are general and common findings in invaded ecosystems, the magnitude of the ecological impact of introduced fish can change a lot among invaded lakes. While scientists devoted a sufficient amount of energy to understand the general ecological consequences of fish presence, there are still many overlooked aspects of the

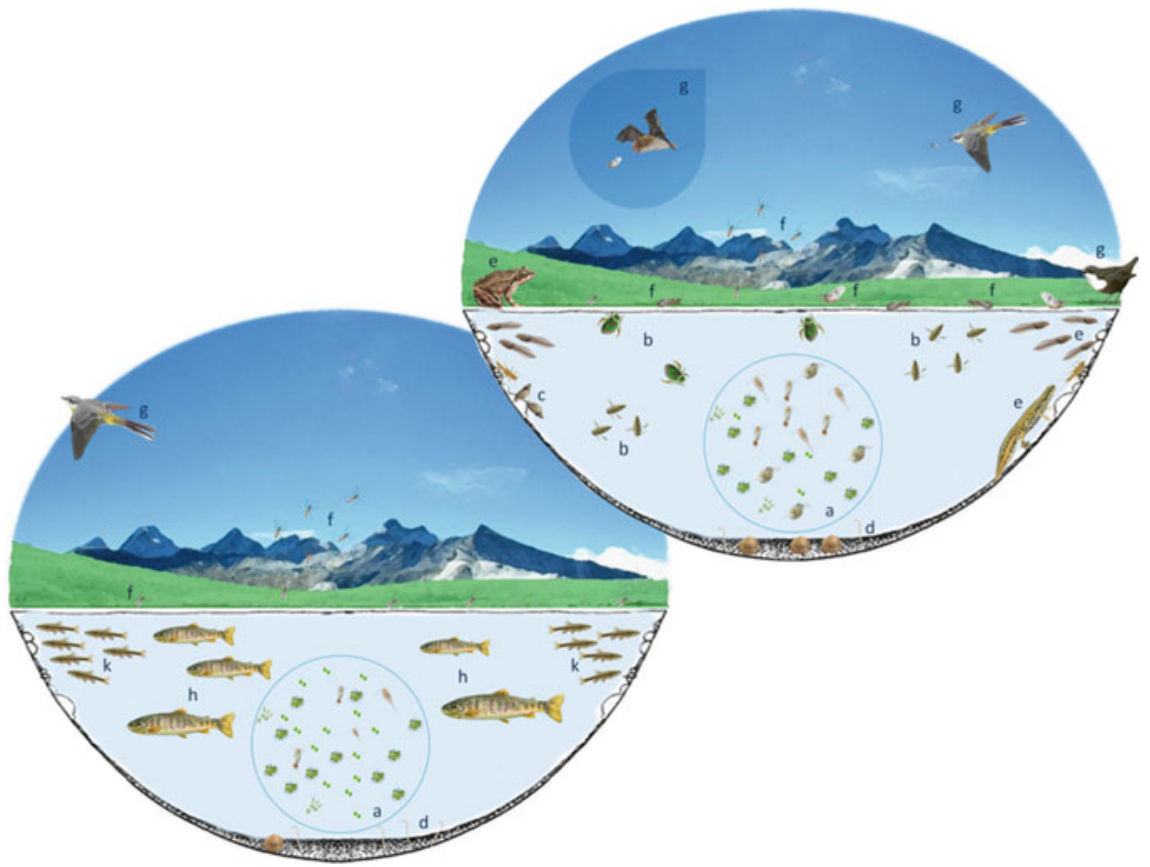

Fig. 8.4 Stocking fishes into originally fishless high mountain lakes results in a series of effects that cascade through the food web: (a) direct predation can affect large planktonic crustaceans and produce indirect top-down and cascading effects altering the communities and biomasses of small zooplankton species and phytoplankton (Knapp et al. 2001b; Sarnelle and Knapp 2005; Tiberti et al. 2014b); (b) nektonic and (c) benthonic macroinvertebrates often undergo local extinction after fish introduction, while $(d)$ fossorial macroinvertebrates are usually unaffected or indirectly favoured by introduced fish (Knapp et al. 2001b; Tiberti et al. 2014b); (e) fish introduction is often a factor of ecological exclusion for amphibians (Bradford et al. 1993; Vredenburg 2004; Tiberti and von Hardenberg 2012; Knapp et al. 2016); (f) introduced fish can alter the aquatic nutrient subsidy (in the form of emerging insects and amphibians) entering the terrestrial environment (Pope et al. 2009; Tiberti et al. 2016b) and indirectly affect $(g)$ terrestrial predators, such as birds, reptiles, amphibians, spiders and bats (Matthews et al. 2002; Finlay and Vredenburg 2007; Epanchin et al. 2010; Benjamin et al. 2011; Joseph et al. 2011; Gruenstein 2014); $(h)$ salmonid species are usually introduced in high mountain lakes to sustain recreational angling (Bahls 1992; Miró and Ventura 2013); ( $k$ ) small fish species, such as Phoxinus sp., are used as live baits by anglers and often released in high mountain lakes with overlooked, but probably important additive and interactive ecological impacts (Miró and Ventura 2015) 
invasion ecology of high-altitude lakes. The reasons why some lakes show stronger or weaker resistance to fish invaders are still largely speculative or need to be studied in more detail. Indeed understanding the characteristics of the lakes which determine a higher resistance to fish predation and resulting indirect ecological impacts can help high-altitude lakes conservation and management and buffer such a widespread conservation problem. It is generally accepted that ecological complexity and the existence of antipredatory refugia (e.g. aquatic vegetation and the dark refugia in the deeper parts of deep lakes) enhance the resistance of native aquatic communities (Knapp et al. 2001b; Pope et al. 2009). However little is known about many aspects related to:

- The biology of introduced populations: the impact of different trout species has not been compared in detail as well as the dependence between the fish density and the magnitude of the impact.

- The ecology of invaded populations: the existence of metapopulations and the vicinity to fishless lakes could probably contrast the effects of fish predation on many prey species through immigration of new individuals, but, except for amphibians (Vredenburg 2004), this issue has rarely been studied. Also, the egg banks and propagules could subsidise native populations with new individuals and buffer fish predation, but also, in this case, their roles have not been well studied (but see Parker et al. 1996 and Latta et al. 2010). There are also many overlooked aspects concerning the cascading effects of fish introduction (e.g. trophic cascades) and their influence on the ecological connection between invaded lakes and terrestrial habitats (reciprocal terrestrial and aquatic subsidies).

- The role of different fish management practices: the consequences of different fish management practices (fishing bans vs. fishing enabled, periodic fish stocking vs. fish stocking halt) on the magnitude of the ecological impact has not been assessed.

- The evolutionary consequences of fish invasion: introduced species can produce evolutive changes in natives, and the evolutionary component of native/non-native species interactions are likely to be a cutting edge field of research in invasion ecology, with important conservation consequences (Lambrinos 2004; Schoener 2011).

- The interacting threats: the effects of fish can be exacerbated by interaction with other stressors. Airborne pesticides (Davidson and Knapp 2007), infections by moulds (chytridiomycosis; Walker et al. 2010; Rosa et al. 2013; Martel et al. 2013; Vredenburg et al. 2010) and viruses (Price et al. 2014; Teacher 2010), climate changes (Bosch et al. 2007) or increased ultraviolet radiation by ozone layer thinning (Adams et al. 2005), water exploitation and water-level fluctuations, point source of organic pollutants, can interact with introduced fish possibly exacerbating the poor conservation status and the resilience potential of many high altitude lakes at a local and regional scale. For example maintaining fishless lakes or eradicating fish can be considered as a measure to contrast the biodiversity loss due to climate warming, restoring a safe stepping stone habitat for many aquatic organisms forced to find cooler condition with an altitudinal shift. 


\subsection{A Serious Problem for Conservation}

The effects of fish introductions on high mountain lake ecosystems summarised above and at Fig. 8.4 demonstrate unambiguously that there are substantial effects at the lake scale, but it is also a problem at a regional and biogeographic scale, either affecting some particular lakes or individual species.

In the Pyrenees, the number of lakes with introduced fish increases with lake size, with more than half of the lakes $>0.5$ ha and nearly all lakes $>2.5$ ha with introduced fish, representing a $72 \%$ of the lake's total surface area (Fig. 8.5a). Also, half of these lakes have both trout and minnows, and a few dozen with minnow alone (Fig. 8.5b). Fish are usually more present in larger lakes in different high mountain areas (e.g. Matthews and Knapp 1999), since smaller lakes and ponds may freeze completely during winter, and therefore fish disappear naturally. Previous studies at Pyrenean or whole European high mountain region scale show that lake size is one of the main variables explaining organism distributions (Kernan et al. 2009; Catalan et al. 2009), being lakes of larger size (surface area $>10$ ha) those with the most distinctive species groups. Therefore, fish introductions in the Pyrenees have affected more seriously the conservation of larger lakes. Although they are relatively scarce, they occupy more than $75 \%$ of the lake surface area of the Pyrenean lentic waters (Fig. 8.5a). Furthermore, these lakes are also those with a higher proportion of water-level oscillations due to hydroelectrical power stations activity (Catalan et al. 1997), a second stressor that also affects negatively lake ecosystems (Miró 2016).
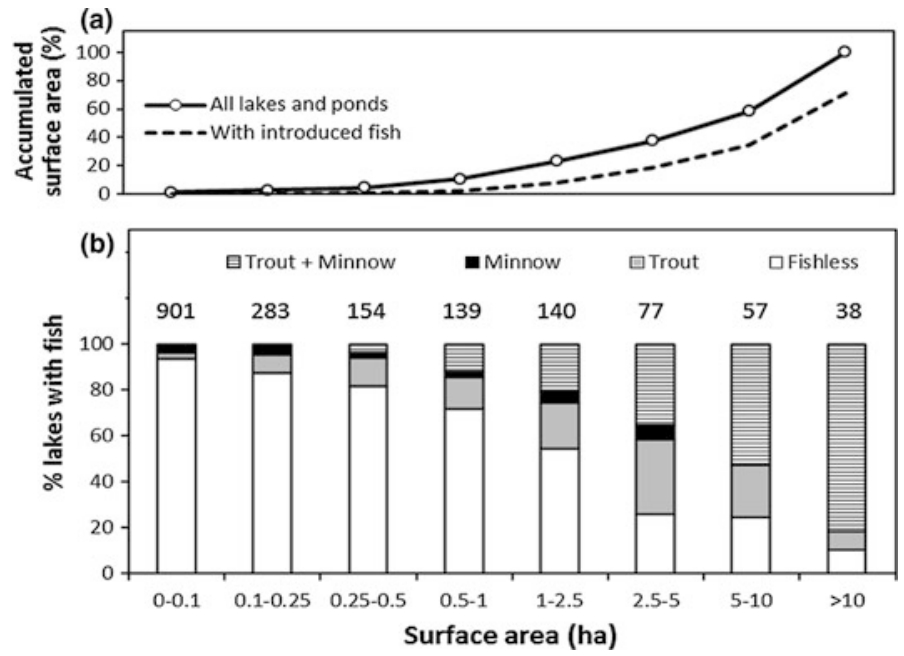

Fig. 8.5 a Percentage of the surface area occupied by lakes and ponds of different size categories in the Pyrenees (straight line) and those with introduced fish (dotted line). b Percentage of lakes without fish (white bars), with introduced fish, distinguishing those with only minnow, trout or both. The proportions include all lakes $>0.5$ ha from (Miró and Ventura 2013, 2015) and ca. 70\% of the ponds (with surface $<0.5$ ha) within the southern slope of the Pyrenees 
The introduction of fish might also affect the conservation status of some species at the metapopulation level depending on their preference for lakes over ponds (Denoël et al. 2016). Most animal groups inhabiting alpine lakes have species better adapted to colonise lakes rather than ponds or vice versa, for example, because lacking desiccation resistance. Figure 8.6 shows the ecological preferences (lakes vs. ponds) of some species of planktonic crustaceans and amphibians. Those preferentially inhabiting lakes are those more threatened by the introduction of fish. Amongst them, the conservation status of the Pyrenean newt [Calotriton asper (Dugès 1852)] is of particular concern since it is an endemic species of the Pyrenees and surrounding areas. For this species, the reduction of its habitat has likely been substantial. Despite it can also be found in fishless upland streams (Oromi et al. 2014), these upland streams have also been affected by modern fish introductions and therefore the reduction in habitat size at its metapopulation scale has been drastically reduced during the 20th century. To what extent this might threaten the future survival of the species is unknown, but its classification within the UICN red list as "nearly threatened" due to habitat loss (Bosch et al. 2009) shows that
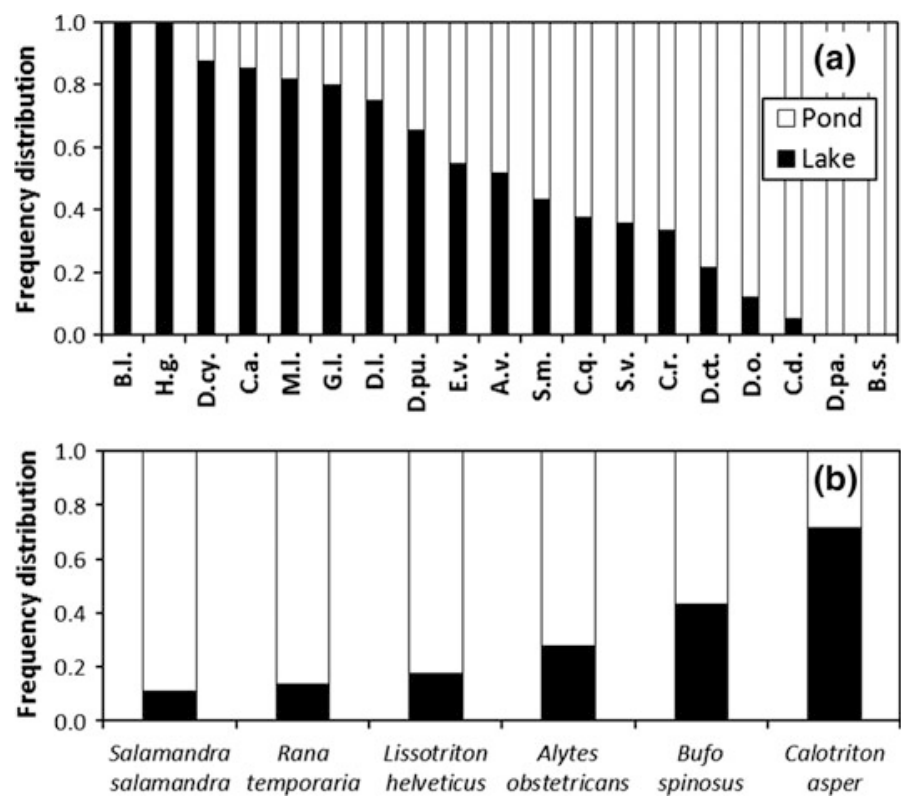

Fig. 8.6 a Probability of finding the different species of planktonic crustaceans and $\mathbf{b}$ amphibians in lakes and ponds (water bodies $>$ or $<0.5$ ha respectively). B.l. Bosmina longirostris, H.g. Holopedium gibberum, D.cy. Diaptomus cyaneus, C.a. Cyclops abyssorum, M.1. Mixodiaptomus laciniatus, G. 1. Gammarus, cf. alpinus, D.1. Daphnia longispina, D.pu. Daphnia pulicaria, E.v. Eudiaptomus vulgaris, A.v. Acanthocyclops vernalis, S.m. Scapholeberis mucronata, C.q. Ceriodaphnia quadrangula, S.v. Simocephalus vetulus, C.r. Ceriodaphnia reticulata, D.ct. Diaptomus castaneti, D.o. Daphnia obtusa, C.d. Chirocephalus diaphanus, D.pa. Daphnia parvula, B.s. Branchipus schaefferi 
invasive fish can seriously threaten the conservation of some of these species. This can also be the case of other species with wider distribution, either because their distribution is restricted to high mountain areas (fish introductions in mountain areas are a global threat; Hulme et al. 2009) or because a synergy with other stressors also affecting the remaining distribution area (e.g. Davis et al. 2010; Ban et al. 2014; Matthaei et al. 2010). Recent genetic studies have also shown that for other species with wide geographic distribution there are genetically differentiated lineages in high mountain areas (Ventura et al. 2014; e.g. Bellati et al. 2014), that might also be at risk of disappearance.

To what extent this substantial habitat loss is indeed affecting the survival of some of the native species is not well known for most of them. Theoretical studies point out that species-specific empirical studies are required with great urgency. If the decrease of habitats is fast, as occurred with the habitat destruction due to fish introductions during the twentieth century in the Pyrenees (see above), there may be a time lag before colonisation and extinction dynamics of the native species reach equilibrium with current habitat distributions (defined as "non-equilibrium dynamics" by Harrison 1991). As a result, species may persist for some time in habitat networks, although they might go extinct some years later even without further landscape change due to a time lag delay (defined as "extinction debt" by Tilman et al. 1994). The apparent survival of species in networks that are insufficient for their long-term persistence may cause underestimates of the area and quality of habitat needed to preserve threatened taxa (Hanski et al. 1996), and overestimates of the species richness that landscapes can support in the long term (Tilman et al. 1994). Therefore, the prevalence of nonequilibrium systems among rare species or lineages, and the implications for their conservation need to be determined as soon as possible (Bulman et al. 2007). However, urgent conservation measures are needed, meanwhile these species-specific studies are not available.

\subsection{Conservation and Restoration, What Has Been Done so Far?}

\subsubsection{Protection Measures}

Different initiatives have been implemented to stop species invasions at various administrative scales. At European scale, the EU regulation 1141/2016 provides a list of invasive alien species considered to be of Union concern ("the Union list"), which does not include any fish species commonly used for stocking mountain lakes. However the regulation contains an invitation for the Member States to counteract the negative effects of some invasive alien species of national or regional concern also cooperating at a regional scale (e.g. mountain ranges). The alien invasive species of national or regional concern can be native in some European Member States and, therefore, Member States could correctly undertake actions to contrast all the species commonly used to stock mountain lakes. At present, there 
are different legislations at the different EU Member States that regulate some introduced species (mainly those introduced from America). However, stocking several salmonid species is currently allowed and, surprisingly, it is usually sustained or approved by governmental agencies (Miró and Ventura 2013), being in clear contradiction with conservation legislation. ${ }^{1}$ The most ambitious initiative existent at European scale is the Natura 2000 network, aiming to protect all species and habitats of special conservation concern (included in the habitats directive). Member States are committed to guarantee the conservation of Natura 2000 habitats and species which, for the case of high mountain lakes and some of their species (e.g. some amphibians, aquatic plants and invertebrates), is incompatible with allowing fish introductions.

Data from the western USA showed that areas with different angling management practices have a different probability of finding introduced trout in high mountain lakes, which is lower in National Parks where fishing is prohibited (Knapp 1996; Wiley 2003). Within the Pyrenees, Miró and Ventura (2013, 2015) compared the spread of new fish introductions among different areas of the Aigüestortes i Estany de Sant Maurici National Park and found that in the area where fishing has been forbidden since 1988, the number of lakes with fish stopped increasing just at the time of the prohibition, while at the other areas, it continued to increase (Fig. 8.7). These common findings in several mountain areas over the world illustrate that the only management practice that has had a positive effect up to present in the protection of lakes is the prohibition of fishing.

Although the most obvious route to avoid introductions would be for governmental agencies to stop stocking trout, this is complicated by the fact that there have been several other agents involved in these introductions in addition to governmental agencies through the history of trout introductions (e.g. local citizens in the past or local fishermen's societies in the past decades). As a result, Miró and Ventura $(2013,2015)$ found some lakes that have been stocked recently without the collaboration of the administration.

In this context, protected areas sometimes provide the favourable local context (i.e. the presence of a surveillance personnel) which is essential to enforce the protection measures (fishing ban, stocking halt) and restoration projects (fish eradications). Therefore, a new and general attitude of mountain protected areas towards less permissive policies concerning fish management is the first and most urgent measure to stem the ecological consequences of the fish invasion.

\footnotetext{
${ }^{1}$ Council Decision 93/626/EEC of 25 October 1993 concerning the conclusion of the Convention on Biological Diversity (OJ L 309, 13.12.1993, p. 1); Regulation 1143/2014 of the European Parliament and of the Council of 22 October 2014 on the prevention and management of the introduction and spread of invasive alien species (OJ L 317, 4.11.2014, p. 1); Directive 2000/60/EC of the European Parliament and of the Council of 23 October 2000 establishing a framework for Community action in the field of water policy (OJ L 327, 22.12.2000, p. 1); Commission Implementing Regulation (EU) 2016/1141 of 13 July 2016 adopting a list of invasive alien species of Union concern pursuant to Regulation (EU) No 1143/2014 of the European Parliament and of the Council C/2016/4295 (OJ L 189, 14.7.2016, pp. 4-8).
} 
(a)

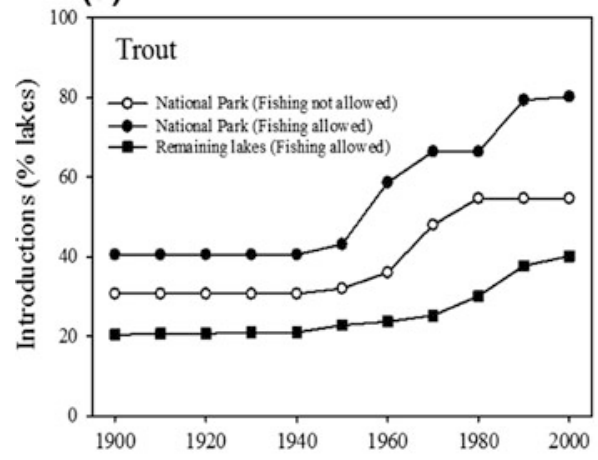

(b)

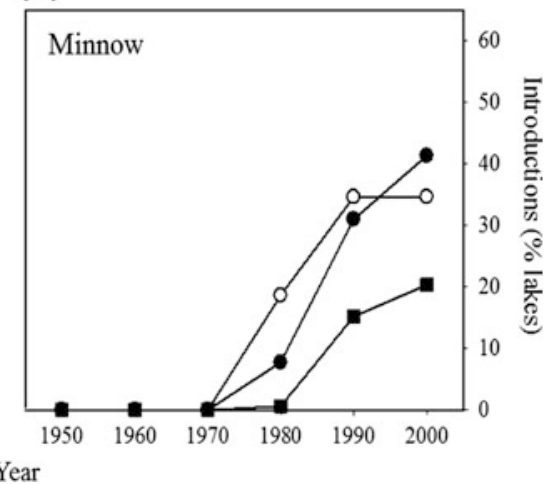

Fig. 8.7 a Effect of not allowing fishing in Aigüestortes i Estany de Sant Maurici National Park on the spread of trout and $\mathbf{b}$ minnows in high mountain lakes of the southern Pyrenees. Circles are the lakes within the National Park, and squares are lakes outside the National Park. White circles are the area of the National Park where fishing is not allowed, and black circles and squares are the lakes in fishing allowed areas. Data from Miró and Ventura (2013, 2015)

The social implications of prohibiting fishing would not be relevant if the prohibition is implemented in those lakes that are at present fishless (at the moment there is the paradox that some lakes have fishing rights while never being stocked with fish). It could also be implemented in some particular lakes or groups of lakes that are especially important for the conservation of some animal groups (e.g. Pyrenean newt $C$. asper). Finally, prohibition on fishing a proportion of the lakes has already been performed in the Aigüestortes i Estany de Sant Maurici National Park, with no documented adverse social impact: basically local citizens realised that the social benefits of nature preservation (through higher tourism) have been greater than those that were obtained via fishing.

\subsubsection{Restoration Projects: Techniques Used and Successful Cases}

Due to the substantial reduction in habitat size directly associated with fish introductions, different protected areas of the world have started restoration projects with the aim to eradicate trout in high altitude lakes. The method most widely used in lentic systems is gill netting (e.g. Knapp and Matthews 1998; Parker et al. 2001; Vredenburg 2004; Knapp et al. 2007; Pacas and Taylor 2015). The most successful ones at removing non-native fishes have focused in relatively small lakes (e.g. Knapp and Matthews 1998; Parker et al. 2001; Vredenburg 2004; Knapp et al. 2007), but this technique demonstrated to be effective also in relatively large high altitude lakes (Pacas and Taylor 2015). The use of gill netting is often 
complemented with electrofishing (Pacas and Taylor 2015), and in one case with local fishermen (Tiberti et al. 2016a). Piscicides (e.g. rotenone and antimycin) have also been used to eradicate fish (e.g. Sanni and Wærvågen 1998; Gresswell 1991). However, their use has ecological effects on native fauna such as invertebrates (e.g. Dalu et al. 2015; Kjærstad and Arnekleiv 2011), and legal and social complications, especially in protected areas because the very notion of a protected area implies that it remains chemical free. It is important to highlight that eradication actions are a "second step", which should come when protection measures (fishing ban and the prohibition of fish stocking) are already in place and effectively enforced; if these fundamental guarantees are absent or weak, the local context (i.e. concrete risk of sabotage of the conservation actions) might suggest deferring the project to future times.

The most ambitious projects have been carried out in North America both USA and Canada (e.g. Knapp and Matthews 1998; Parker et al. 2001; Vredenburg 2004; Knapp et al. 2007; Pacas and Taylor 2015). In Europe, removal of brook trout has also been achieved in a small alpine lake in the central Iberian Peninsula (Toro et al. 2006). Furthermore, two recent European Commission funded projects, the LIFE+ Bioaquae (www.bioaquae.eu) and LIFE+ LimnoPirineus (www.lifelimnopirineus. eu) are removing fish from different high mountain lakes. The former started removing brook trout from four lakes and their surrounding streams of the Gran Paradiso National Park (Italian Alps) in 2013 (Tiberti et al. 2013), having already removed fish from all lakes (R. Tiberti, Pers. Comm.). The latter started at 2015 in the Pyrenees (Aigüestortes i Estany de Sant Maurici National Park and Alt Pirineu Natural Park) and is aiming at removing brook trout, rainbow trout, brown trout and European minnow from eight lakes and their surrounding streams. Three of them have minnow only, two both minnow and brown trout, two brook trout and one rainbow trout.

Studies of the recovery of restored lakes have shown the relatively fast recovery of lake populations when surrounding refugees are available (Knapp et al. 2001b, 2005, 2007; Sarnelle and Knapp 2004), being amphibians and macroinvertebrates those with faster recovery (Knapp et al. 2001b, 2005, 2007), and crustacean zooplankton the later (Knapp and Sarnelle 2008). These latter authors have also shown that some species producing resistance eggs are not able to survive for many years in the egg bank (e.g. calanoid copepods). Fish residence times (years that fish have been in the lake) above ca. 50 years greatly reduce the fast recovery of these species from the egg bank.

Acknowledgements The authors would like to acknowledge those people that provided information about fish introductions, two anonymous reviewers and the editors for giving us the opportunity to participate in the workshop and writing this paper. This book chapter is a joint contribution of the LIFE+ projects BIOAQUAE (Biodiversity Improvement of Aquatic Alpine Ecosystems, LIFE11 BIOIT000020) and LIMNOPIRINEUS (Restoration of lentic habitats and aquatic species of Community interest in high mountains of the Pyrenees, LIFE13 NAT/ES/001210). RT thanks the University of Pavia and Bruno Bassano and Giuseppe Bogliani for their support. DB benefitted from a scholarship from Government of Ecuador (SENESCYT 20090187-20130946) and IS from a Catalan Government grant (2015 FI_B 01147). 


\section{References}

Adams MJ, Hossack BR, Knapp RA, Corn PS, Diamond SA, Trenham PC, Fagre DB (2005) Distribution patterns of lentic-breeding amphibians in relation to ultraviolet radiation exposure in western North America. Ecosystems 8:488-500

Adams SB, Frissell CA, Rieman BE (2001) Geography of invasion in mountain streams: consequences of headwater lake fish introductions. Ecosystems 4:296-307

Araguas RM, Sanz N, Fernández F, Utter FM, Pla C, García-Marín J-L (2009) Role of genetic refuges in the restoration of native gene pools of brown trout. Conserv Biol 23:871-878

Armstrong TW, Knapp RA (2004) Response by trout populations in alpine lakes to an experimental halt to stocking. Can J Fish Aquat Sci 61:2025-2037

Bahls P (1992) The status of fish populations and management of high mountain lakes in the Western United States. Northwest Sci 66:183-193

Ban SS, Graham NAJ, Connolly SR (2014) Evidence for multiple stressor interactions and effects on coral reefs. Glob Change Biol 20:681-697

Beebee TJC, Griffiths RA (2005) The amphibian decline crisis: a watershed for conservation biology? Biol Conserv 125:271-285

Bellati A, Tiberti R, Cocca W, Galimberti A, Casiraghi M, Bogliani G, Galeotti P (2014) A dark shell hiding great variability: a molecular insight into the evolution and conservation of melanic Daphnia populations in the Alps. Zool J Linn Soc 171:697-715

Benjamin JR, Fausch KD, Baxter CV (2011) Species replacement by a nonnative salmonid alters ecosystem function by reducing prey subsidies that support riparian spiders. Oecologia 167:503-512

Borgstrom R, Garnas E, Salveit SJ (1985) Interactions between brown trout, Salmo trutta (L.), and minnow, Phoxinus phoxinus (L.), for their common prey, Lepidurus arcticus (Pallas). Ver Internat Verein Limnol 22:2548-2552

Borgstrøm R, Brittain JE, Hasle K, Skjølås S, Dokk JG (1996) Reduced recruitment in brown trout Salmo trutta, the role of interactions with minnow Phoxinus phoxinus. Nord J Freshw Res 72:30-38

Bosch J, Rincon PA, Boyero L, Martinez-Solano I (2006) Effects of introduced salmonids on a montane population of Iberian frogs. Conserv Biol 20:180-189

Bosch J, Carrascal LM, Duran L, Walker S, Fisher MC (2007) Climate change and outbreaks of amphibian chytridiomycosis in a montane area of Central Spain; is there a link? Proc Roy Soc Lond B Bio 274:253-260

Bosch J, Tejedo M, Lecis R, Miaud C, Lizana M, Edgar P, Martínez-Solano I, Salvador A, García-París M, Recuero Gil E, Marquez R, Geniez P (2009) Calotriton asper (Publication no. http://dx.doi.org/10.2305/IUCN.UK.2009.RLTS.T59448A11943040.en)

Bradford DF, Tabatabai F, Graber DM (1993) Isolation of remaining populations of the native frog, Rana muscosa, by introduced fishes in Sequoia and Kings Canyon National-Parks, California. Conserv Biol 7:882-888

Brancelj A (2000) The extinction of Arctodiaptomus alpinus (Copepoda) following the introduction of charr into a small alpine lake Dvojno Jezero (NW Slovenia). Aquat Ecol 33:355-361

Brancelj A, Sisko M, Brancelj IR, Jeran Z, Jacimovic R (2000) Effects of land use and fish stocking on a mountain lake-evidence from the sediment. Period Biol 102:259-268

Brooks JL, Dodson SI (1965) Predation, body size, and composition of plankton. Science 150:28-35

Buchaca T, Skov T, Amsinck SL, Gonçalves V, Neto Azevedo JM, Andersen TJ, Jeppesen E (2011) Rapid ecological shift following piscivorous fish introduction to increasingly eutrophic and warmer Lake Furnas (Azores Archipelago, Portugal): a paleoecological approach. Ecosystems 14:458-477

Bulman CR, Wilson RJ, Holt AR, Bravo LG, Early RI, Warren MS, Thomas CD (2007) Minimum viable metapopulation size, extinction debt, and the conservation of a declining species. Ecol Appl 17:1460-1473 
Callaham MA Jr, Gonzalez G, Hale CM, Heneghan L, Lachnicht SL, Zou X (2006) Policy and management responses to earthworm invasions in North America. Biol Invasions 8:1317-1329

Cambray JA (2003) Impact on indigenous species biodiversity caused by the globalisation of alien recreational freshwater fisheries. Hydrobiologia 500:217-230

Cantonati M, Lapini L, Paradisi S, Stoch F (2006) Conservation and management. In: Stoch F (ed) High-altitude lakes. Quaderni habitat vol 14. Ministero dell'Ambiente e della Tutela del Territorio. Museo Friulano di Storia Naturale. English Edition: Italian Habitats, pp 123-135

Carpenter SR, Cole JJ, Pace ML, Batt R, Brock WA, Cline T, Coloso J, Hodgson JR, Kitchell JF, Seekell DA, Smith L, Weidel B (2011) Early warnings of regime shifts: a whole-ecosystem experiment. Science 332:1079-1082

Catalan J, Vilalta R, Weitzman B, Ventura M, Comas E, Pigem C, Aranda R, Ballesteros E, Camarero L, García Serrano J, Pla S, Sáez A, Aiguabella P (1997) The hydraulic industry in the Pyrenees: evaluation, correction and prevention of the environmental impact at the Aigüestortes i Estany de Sant Maurici National Park. La Caixa, Barcelona

Catalan J, Barbieri MG, Bartumeus F, Bitusik P, Botev I, Brancelj A, Cogalniceanu D, Garcia J, Manca M, Marchetto A, Ognjanova-Rumenova N, Pla S, Rieradevall M, Sorvari S, Stefkova E, Stuchlik E, Ventura M (2009) Ecological thresholds in European alpine lakes. Freshw Biol 54:2494-2517

Collen B, Whitton F, Dyer EE, Baillie JEM, Cumberlidge N, Darwall WRT, Pollock C, Richman NI, Soulsby A-M, Böhm M (2014) Global patterns of freshwater species diversity, threat and endemism. Glob Ecol Biogeogr 23:40-51

Cowx IG, Gerdeaux D (2004) The effects of fisheries management practises on freshwater ecosystems. Fish Manag Ecol 11:145-151

Christenson DP (1977) History of trout introductions in California high mountain lakes. In: Hall A (ed) A symposium on the management of high mountain lakes in California's National Parks, San Francisco, California, 9-16 May 1977, vol 1. California Trout Inc., pp 9-15

Dalu T, Wasserman RJ, Jordaan M, Froneman WP, Weyl OLF (2015) An assessment of the effect of rotenone on selected non-target aquatic fauna. PLoS ONE 10:e0142140

Davidson C, Knapp RA (2007) Multiple stressors and amphibian declines: dual impacts of pesticides and fish on yellow-legged frogs. Ecol Appl 17:587-597

Davis J, Sim L, Chambers J (2010) Multiple stressors and regime shifts in shallow aquatic ecosystems in antipodean landscapes. Freshw Biol 55:5-18

Dawidowicz P, Gliwicz ZM (1983) Food of brook charr in extreme oligotrophic conditions of an alpine lake. Environ Biol Fishes 8:55-60

de Mendoza G, Rico E, Catalan J (2012) Predation by introduced fish constrains the thermal distribution of aquatic Coleoptera in mountain lakes. Freshw Biol 57:803-814

Delacoste M, Baran P, Lascaux JM, Abad N, Besson JP (1997) Evaluation of salmonid introductions in high-elevation lakes and streams of the Hautes-Pyrenees region. Bull Fr Peche Piscic 205-219

Denoël M, Scimè P, Zambelli N (2016) Newt life after fish introduction: extirpation of paedomorphosis in a mountain fish lake and newt use of satellite pools. Curr Zol 62:61-69

DiStefano RJ, Litvan ME, Horner PT (2009) The bait industry as a potential vector for alien crayfish introductions: problem recognition by fisheries agencies and a Missouri evaluation. Fisheries 34:586-597

Eby LA, Roach WJ, Crowder LB, Stanford JA (2006) Effects of stocking-up freshwater food webs. Trends Ecol Evol 21:576-584

Emery L (1985) Review of fish species introduced into the Great Lakes, 1819-1974, vol 45. Great Lakes Fishery Commission Technical Report. Great Lakes Fisheri Commission, Ann Arbor, MI

Epanchin PN, Knapp RA, Lawler SP (2010) Nonnative trout impact an alpine-nesting bird by altering aquatic insect subsidies. Ecology 91:2406-2415

FAO (2003) Fishery records collections. FIGIS data collection, Inland Water Resources and Aquaculture Service (FIRI). http://www.fao.org/figis/servlet/static?dom=collection\&xml=dias. $\mathrm{xml}$ 
Finlay JC, Vredenburg VT (2007) Introduced trout sever trophic connections in watersheds: Consequences for a declining amphibian. Ecology 88:2187-2198

Frezet C (2003) Catasto dei laghi valdostani. ARPA Valle d'Aosta

Garcia-Berthou E, Moreno-Amich R (2000) Introduction of exotic fish into a Mediterranean lake over a 90-year period. Arch Hydrobiol 149:271-284

Gido KB, Schaefer JF, Pigg J (2004) Patterns of fish invasions in the Great Plains of North America. Biol Conserv 118:121-131

Gliwicz ZM, Rowan MG (1984) Survival of Cyclops abyssorum tatricus (Copepoda, Crustacea) in alpine lakes stocked with planktivorous fish. Limnol Oceanogr 29:1290-1299

Granek EF, Madin EMP, Brown MA, Figueira W, Cameron DS, Hogan Z, Kristianson G, De Villiers P, Williaims JE, Post J, Zahn S, Arlinghaus R (2008) Engaging recreational fishers in management and conservation: global case studies. Conserv Biol 22:1125-1134

Gratton C, Donaldson J, Vander Zanden MJ (2008) Ecosystem linkages between lakes and the surrounding terrestrial landscape in northeast Iceland. Ecosystems 11:764-774

Gresswell RE (1991) Use of antimycin for removal of brook trout from a tributary of yellowstone lake. N Am J Fish Manag 11:83-90

Gruenstein E (2014) The response of bats to introduced trout in naturally fishless lakes Sierra Nevada. San José State University, California Master's Theses

Hall D, Threlkeld ST, Burns CW, Crowley PH (1976) The size-efficiency hypothesis and the size structure of zoplankton communities. Annu Rev Ecol Syst 7:177-208

Hanski I, Moilanen A, Gyllenberg M (1996) Minimum viable metapopulation size. Am Nat 147:527-541

Harrison S (1991) Local extinction in a metapopulation context: an empirical evaluation. Biol J Linn Soc 42:73-88

Hesthagen T, Hegge O, Skurdal J (1992) Food choice and vertical distribution of European minnow, Phoxinus phoxinus, and young native and stocked brown trout, Salmo trutta, in the littoral zone of a subalpine lake. Norw J Freshwat Res 67:72-76

Hulme PE, Nentwig W, Pyšek P, Vilà M (eds) (2009) DAISIE Handbook of alien species in Europe, vol 3. Invading nature. Springer series in invasion ecology. Springer, Dordrecht

Jersabek CD, Brancelj A, Stoch F, Schabetsberger R (2001) Distribution and ecology of copepods in mountainous regions of the Eastern Alps. Hydrobiologia 453-454:309-324

Joseph MB, Piovia-Scott J, Lawler SP, Pope KL (2011) Indirect effects of introduced trout on Cascades frogs (Rana cascadae) via shared aquatic prey. Freshw Biol 56:828-838

Keller RP, Lodge DM (2007) Species invasions from commerce in live aquatic organisms: problems and possible solutions. Bioscience 57:428-436

Kernan M, Ventura M, Brancelj A, Clarke G, Raddum G, Stuchlík E, Catalan J (2009) Regionalisation of remote European mountain lake ecosystems according to their biota: environmental versus geographical patterns. Freshw Biol 54:2470-2493

Kerr SJ, Brousseau CS, Muschett M (2005) Invasive aquatic species in Ontario: a review and analysis of potential pathways for introduction. Fisheries 30:21-30

Kilian JV, Klauda RJ, Widman S, Kashiwagi M, Bourquin R, Weglein S, Schuster J (2012) An assessment of a bait industry and angler behavior as a vector of invasive species. Biol Invasions 14:1469-1481

Kjærstad G, Arnekleiv JV (2011) Effects of rotenone treatment on lotic invertebrates. Int Rev Hydrobiol 96:58-71

Knapp RA (1996) Non-native trout in natural lakes of the Sierra Nevada: an analysis of their distribution and impacts on native aquatic biota. In: Sierra Nevada Ecosystem Project: Final Report to Congress, 1996. UC Davis

Knapp RA (2005) Effects of nonnative fish and habitat characteristics on lentic herpetofauna in Yosemite National Park, USA. Biol Conserv 121:265-279

Knapp RA, Matthews KR (1998) Eradication of nonnative fish by gill netting from a small mountain lake in California. Restor Ecol 6:207-213

Knapp RA, Sarnelle O (2008) Recovery after local extinction: factors affecting re-establishment of alpine lake zooplankton. Ecol Appl 18:1850-1859 
Knapp RA, Corn PS, Schindler DE (2001a) The introduction of nonnative fish into wilderness lakes: good intentions, conflicting mandates, and unintended consequences. Ecosystems 4:275-278

Knapp RA, Matthews KR, Sarnelle O (2001b) Resistance and resilience of alpine lake fauna to fish introductions. Ecol Monogr 71:401-421

Knapp RA, Hawkins CP, Ladau J, McClory JG (2005) Fauna of Yosemite National Park lakes has low resistance but high resilience to fish introductions. Ecol Appl 15:835-847

Knapp RA, Boiano DM, Vredenburg VT (2007) Removal of nonnative fish results in population expansion of a declining amphibian (mountain yellow-legged frog, Rana muscosa). Biol Conserv 135:11-20

Knapp RA, Fellers GM, Kleeman PM, Miller DAW, Vredenburg VT, Rosenblum EB, Briggs CJ (2016) Large-scale recovery of an endangered amphibian despite ongoing exposure to multiple stressors. Proc Natl Acad Sci USA. doi:10.1073/pnas.1600983113

Knight TM, McCoy MW, Chase JM, McCoy KA, Holt RD (2005) Trophic cascades across ecosystems. Nature 437:880-883

Lambrinos JG (2004) How interactions between ecology and evolution influence contemporary invasion dynamics. Ecology 85:2061-2070

Latta LC, Fisk DL, Knapp RA, Pfrender ME (2010) Genetic resilience of Daphnia populations following experimental removal of introduced fish. Conser Genet 11:1737-1745

Lindgren CJ (2006) Angler awareness of aquatic invasive species in Manitoba. J Aquat Plant Manag 44:103-108

Litvak MK, Mandrak NE (1993) Ecology of fresh-water baitfish use in Canada and the United-States. Fisheries 18:6-13

Lowe S, Browne M, Boudjelas S, De Poorter M (2000) 100 of the worlds worst invasive alien species A selection from the global invasive species database. World Conservation Union (IUCN)

Machino Y (1999) History and status of Arctic charr introductions in southern Europe. Int Soc Artic Charr Fanatics, Drottningholm, Sweden Inf Ser 7:33-39

Magnea U, Sciascia R, Paparella F, Tiberti R, Provenzale A (2013) A model for high-altitude alpine lake ecosystems and the effect of introduced fish. Ecol Model 251:211-220

Maitland PS, Campbell RN (1992) Freshwater fishes of the British Isles, vol Book. Whole, Harper Collins, London

Mammoliti Mochet A (1995) Analisi dell'ittiofauna in Valle d'Aosta allo stato attuale e allo stato pregresso. Università degli Studi di Torino

Marchetti MP, Light T, Moyle PB, Viers JH (2004) Fish invasions in California watersheds: testing hypotheses using landscape patterns. Ecol Appl 14:1507-1525

Martel A, Spitzen-van der Sluijs A, Blooi M, Bert W, Ducatelle R, Fisher MC, Woeltjes A, Bosman W, Chiers K, Bossuyt F, Pasmans F (2013) Batrachochytrium salamandrivorans sp. nov. causes lethal chytridiomycosis in amphibians. Proc Natl Acad Sci USA 110:15325-15329

Martín-Torrijos L, Sandoval-Sierra JV, Muñoz J, Diéguez-Uribeondo J, Bosch J, Guayasamin JM (2016) Rainbow trout (Oncorhynchus mykiss) threaten Andean amphibians. Neotrop Biodiver 2:26-36

Martinez-Solano I, Barbadillo LJ, Lapena M (2003) Effect of introduced fish on amphibian species richness and densities at a montane assemblage in the Sierra de Neila, Spain. Herpetol $\mathbf{J}$ 13:167-173

Matthaei CD, Piggott JJ, Townsend CR (2010) Multiple stressors in agricultural streams: interactions among sediment addition, nutrient enrichment and water abstraction. J Appl Ecol 47:639-649

Matthews KR, Knapp RA (1999) A study of high mountain lake fish stocking effects on the U.S. Sierra Nevada wilderness. Int J Wilderness 5:24-26

Matthews KR, Knapp RA, Pope KL (2002) Garter snake distributions in high-elevation aquatic ecosystems: is there a link with declining amphibian populations and nonnative trout introductions? J Herpetol 36:16-22

McRae L, Freeman R, Deinet S (2014) The Living Planet Index. In: McLellan R, Iyengar L, Jeffries B, Oerlemans N (eds) Living planet report 2014. Species and spaces, people and places. World Wild Fund International, Gland, Switzerland 
Migge-Kleian S, McLean MA, Maerz JC, Heneghan L (2006) The influence of invasive earthworms on indigenous fauna in ecosystems previously uninhabited by earthworms. Biol Invasions 8:1275-1285

Mills CA (1988) The effect of extreme northerly climatic conditions on the life history of the minnow, Phoxinus phoxinus (L.). J Fish Biol 33:545-561

Miró A (2011) Trout in Pyrenean Lakes: tradition, history and conservation implications (In Catalan). Pagès Editors, Lleida

Miró A (2016) Fish as local stressors of Pyrenean high mountain lakes: arrival process and impact on amphibians and other organisms. PhD Thesis, University of Barcelona, Barcelona

Miró A, Ventura M (2013) Historical use, fishing management and lake characteristics explain the presence of non-native trout in Pyrenean lakes: Implications for conservation. Biol Conserv 167:17-24

Miró A, Ventura M (2015) Evidence of exotic trout mediated minnow invasion in Pyrenean high mountain lakes. Biol Invasions 17:791-803

Museth J, Borgstrom R, Hame T, Holen LA (2003) Predation by brown trout: a major mortality factor for sexually mature European minnows. J Fish Biol 62:692-705

Museth J, Hesthagen T, Sandlund OT, Thorstad EB, Ugedal O (2007) The history of the minnow Phoxinus phoxinus (L.) in Norway: from harmless species to pest. J Fish Biol 71:184-195

Museth J, Borgstrom R, Brittain JE (2010) Diet overlap between introduced European minnow (Phoxinus phoxinus) and young brown trout (Salmo trutta) in the lake, Øvre Heimdalsvatn: a result of abundant resources or forced niche overlap? Hydrobiologia 642:93-100

Orizaola G, Braa F (2006) Effect of salmonid introduction and other environmental characteristics on amphibian distribution and abundance in mountain lakes of northern Spain. Anim Conserv 9:171-178

Oromi N, Amat F, Sanuy D, Carranza S (2014) Life history trait differences between a lake and a stream-dwelling population of the Pyrenean brook newt (Calotriton asper). Amphib-Reptilia 35:53-62

Ortega H, Guerra H, Ramírez R (2007) The introduction of nonnative fishes into freshwater systems of Peru. In: Ecological and genetic implications of aquaculture activities. Springer, pp $247-278$

Pacas C, Taylor M (2015) Nonchemical eradication of an introduced trout from a headwater complex in Banff National Park, Canada. N Am J Fish Manag 35:748-754

Parker BR, Wilhelm FM, Schindler DW (1996) Recovery of Hesperodiaptomus arcticus populations from diapausing eggs following elimination by stocked salmonids. Can J Zool 74:1292-1297

Parker BR, Schindler DE, Donald DB, Anderson RS (2001) The effects of stocking and removal of a non-native brook trout on the plankton populations of an alpine lake. Ecosystems 4:334-345

Pechlaner R (1984) Historical evidence for the introduction of Arctic charr into high-mountain lakes of the Alps by man. In: Burns BL (ed) Johnson J. University of Manitoba Press, Winnipeg, pp 449-557

Peters JA, Lodge DM (2009) Invasive species policy at the regional level: a multiple weak links problem. Fisheries 34:373-381

Petr T (1999) Fish and fisheries at higher altitudes: Asia, vol 385. Food \& Agriculture Org

Piccinini A, Nonnis Marzano F, Gandolfi G (2004) Il Salmerino alpino (Salvelinus alpinus): prove storiche alla sua introduzione sul territorio italiano. Nonnis Marzano F, Maldini M \& Gandolfi G (eds.). Atti 9:259-264

Pilliod DS, Ricciardi A, Hossack BR, Bahls PF, Bull EL, Corn PS, Hokit G, Maxell BA, Munger JC, Wyrick A (2010) Non-native salmonids affect amphibian occupancy at multiple spatial scales. Divers Distrib 16:959-974

Pister EP (2001) Wilderness fish stocking: history and perspective. Ecosystems 4:279-286

Pope KL (2008) Assessing changes in amphibian population dynamics following experimental manipulations of introduced fish. Conserv Biol 22:1572-1581

Pope KL, Hannelly EC (2013) Response of benthic macroinvertebrates to whole-lake, non-native fish treatments in mid-elevation lakes of the Trinity Alps, California. Hydrobiologia 714:201-215 
Pope KL, Garwood JM, Welsh HH, Lawler SP (2008) Evidence of indirect impacts of introduced trout on native amphibians via facilitation of a shared predator. Biol Conserv 141:1321-1331

Pope KL, Piovia-Scott J, Lawler SP (2009) Changes in aquatic insect emergence in response to whole-lake experimental manipulations of introduced trout. Freshw Biol 54:982-993

Price SJ, Garner TWJ, Nichols RA, Balloux F, Ayres C, Mora-Cabello de Alba A, Bosch J (2014) Collapse of amphibian communities due to an introduced ranavirus. Curr Biol 24:2586-2591

Pringle RM (2005) The origins of the Nile perch in Lake Victoria. Bioscience 55:780-787

Rosa GM, Anza I, Moreira PL, Conde J, Martins F, Fisher MC, Bosch J (2013) Evidence of chytrid-mediated population declines in common midwife toad in Serra da Estrela, Portugal. Anim Conserv 16:306-315

Sanni S, Wærvågen SB (1998) Oligotrophication as a result of planktivorous fish removal with rotenone in the small, eutrophic, Lake Mosvatn, Norway. Hydrobiologia 200:263-274

Sarnelle O, Knapp RA (2004) Zooplankton recovery after fish removal: limitations of the egg bank. Limnol Oceanogr 49:1382-1392

Sarnelle O, Knapp RA (2005) Nutrient recycling by fish versus zooplankton grazing as drivers of the trophic cascade in alpine lakes. Limnol Oceanogr 50:2032-2042

Schabetsberger R, Jersabek CD, Brozek S (1995) The impact of alpine newts (Triturus alpestris) and minnows (Phoxinus phoxinus) on the microcrustacean communities of two high altitude karst lakes. Alytes (Paris) 12:183-189

Schabetsberger R, Luger MS, Drozdowski G, Jagsch A (2009) Only the small survive: monitoring long-term changes in the zooplankton community of an Alpine lake after fish introduction. Biol Invasions 11:1335-1345

Schindler DE, Parker BR (2002) Biological pollutants: alien fishes in mountain lakes. Water Air Soil Pollut Focus 2:379-397

Schindler DE, Knapp RA, Leavitt PR (2001) Alteration of nutrient cycles and algal production resulting from fish introductions into mountain lakes. Ecosystems 4:308-321

Schindler DW (2000) Aquatic problems caused by human activities in Banff National Park. Ambio 29:401-407

Schoener TW (2011) The newest synthesis: understanding the interplay of evolutionary and ecological dynamics. Science 331:426-429

Simberloff D, Martin J-L, Genovesi P, Maris V, Wardle DA, Aronson J, Courchamp F, Galil B, García-Berthou E, Pascal M, Pysek P, Sousa R, Tabacchi E, Vila M (2013) Impacts of biological invasions: what's what and the way forward. Trends Ecol Evol 28:58-66

Sostoa A, Lobón-Cerviá J (1989) Fish and fisheries of the River Ebro: actual state and recent history. In: Petts GE, Mller H, Roux AL (eds) Historical change of large alluvial rivers: Western Europe. Wiley, Chinchester, pp 233-247

Tang KL, Agnew MK, Chen W-J, Hirt MV, Raley ME, Sado T, Schneider LM, Yang L, Bart HL, He S, Liu H, Miya M, Saitoh K, Simons AM, Wood RM, Mayden RL (2011) Phylogeny of the gudgeons (Teleostei: Cyprinidae: Gobioninae). Mol Phylogenet Evol 61:103-124

Teacher AGF (2010) Assessing the long-term impact of Ranavirus infection in wild common frog populations. Anim Conserv 13:514-522

Terrero D (1951) Historia local de piscicultura. Montes 39:165-171

Tiberti R, von Hardenberg A (2012) Impact of introduced fish on Common frog (Rana temporaria) close to its altitudinal limit in alpine lakes. Amphib-Reptilia 33:303-307

Tiberti R, Acerbi E, Iacobuzio R (2013) Preliminary studies on fish capture techniques in Gran Paradiso alpine lakes: towards an eradication plan. J Mountain Ecol 9:61-74

Tiberti R, Brighenti S, Iacobuzio R, Pasquini G, Rolla M (2014a) Behind the impact of introduced trout in high altitude lakes: adult, not juvenile fish are responsible of the selective predation on crustacean zooplankton. J Limnol 73:593-597

Tiberti R, von Hardenberg A, Bogliani G (2014b) Ecological impact of introduced fish in high altitude lakes: a case of study from the European Alps. Hydrobiologia 724:1-19

Tiberti R, Ottino M, Brighenti S, Iacobuzio R, Rolla M, von Hardenberg A, Bassano B (2016a) Involvement of recreational anglers in the eradication of alien brook trout from alpine lakes. J Mountain Ecol 10:13-26 
Tiberti R, Rolla M, Brighenti S, Iacobuzio R (2016b) Changes in the insect emergence at the water-air interface in response to fish density manipulation in high altitude lakes. Hydrobiologia 779:93-104

Tilman D, May RM, Lehman CL, Nowak MA (1994) Habitat destruction and the extinction debt. Nature 371:65-66

Toro M, Granados I, Robles S, Montes C (2006) High mountain lakes of the Central Range Iberian Pennsula): regional limnology \& environmental changes. Limnetica 25:217-252

Ventura M, Petrusek A, Miró A, Hamrová E, Buñay D, De meester L L, Mergeay J (2014) Local and regional founder effects in lake zooplankton persist after thousands of years despite high dispersal potential. Mol Ecol 23:1014-1027

Vigliano PH, Alonso MF (2007) Salmonid introductions in Patagonia: a mixed blessing. In: Ecological and genetic implications of aquaculture activities. Springer, pp 315-331

Villwock W (1994) Consequences of exotic fish introductions on the naitive Lake Titicaca species (in Spanish). Ecología en Bolivia 23:49-56

Vitule JRS, Freire CA, Simberloff D (2009) Introduction of non-native freshwater fish can certainly be bad. Fish Fish 10:98-108

Volta P, Jepsen N (2008) The recent invasion of Rutilus rutilus (L.) (Pisces: Cyprinidae) in a large South-Alpine lake: Lago Maggiore. J Limnol 67:163-170

Vredenburg VT (2004) Reversing introduced species effects: Experimental removal of introduced fish leads to rapid recovery of a declining frog. P Natl Acad Sci USA 101:7646-7650

Vredenburg VT, Knapp RA, Tunstall TS, Briggs CJ (2010) Dynamics of an emerging disease drive large-scale amphibian population extinctions. Proc Natl Acad Sci USA 107:9689-9694

Walker SF, Bosch J, Gomez V, Garner TWJ, Cunningham AA, Schmeller DS, Ninyerola M, Henk DA, Ginestet C, Arthur C-P, Fisher MC (2010) Factors driving pathogenicity vs. prevalence of amphibian panzootic chytridiomycosis in Iberia. Ecol Lett 13:372-382

Ward JM, Cudmore B, Drake DAR, Mandrak NE (2012) Summary of a survey of baitfish users in Canada. Can Manuscr Rep Fish Aquat Sci 2972:i-v, 1-23

Webb AC (2007) Status of non-native freshwater fishes in tropical northern Queensland, including establishment success, rates of spread, range and introduction pathways. J Proc R Soc N S W 140:63-78

Wiley RW (2003) Planting trout in Wyoming high-elevation wilderness waters. Fisheries 28:22-27 Winfield IJ, Fletcher JM, James JB (2011) Invasive fish species in the largest lakes of Scotland, Northern Ireland, Wales and England: the collective UK experience. Hydrobiologia 660:93-103 Zerunian S (2003) Piano d'azione generale per la conservazione dei pesci d'acqua dolce italiani, vol 17. Ministero dell'ambiente e della tutela del territorio, Direzione per la protezione della natura

Open Access This chapter is licensed under the terms of the Creative Commons Attribution 4.0 International License (http://creativecommons.org/licenses/by/4.0/), which permits use, sharing, adaptation, distribution and reproduction in any medium or format, as long as you give appropriate credit to the original author(s) and the source, provide a link to the Creative Commons license and indicate if changes were made.

The images or other third party material in this chapter are included in the chapter's Creative Commons license, unless indicated otherwise in a credit line to the material. If material is not included in the chapter's Creative Commons license and your intended use is not permitted by statutory regulation or exceeds the permitted use, you will need to obtain permission directly from the copyright holder.

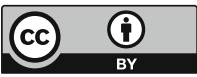

